\title{
HISTORICAL OCCURRENCE OF WHITE-TAILED PTARMIGAN IN WYOMING
}

\author{
Clait E. Braun ${ }^{1}$ and Gregory T. Wann ${ }^{2}$
}

\begin{abstract}
Aвstract.-We found 13 specimens (11 museum skins, 2 skeletons) of White-tailed Ptarmigan (Lagopus leucura) collected in Wyoming. All were collected in the 1911-1967 period: 12 from the Snowy Range (Albany County) and one from near Encampment (Carbon County). The last verifiable observations of White-tailed Ptarmigan in the Snowy Range were 2 separate reports in 1974, both of 4 individuals in the same location. A more recent report of 2 birds north of the Snowy Range on 15 October 2005 has also been verified. None of the verifiable observations or collection events was of more than 6 individuals. Most of the published observation records from areas other than in the Snowy Range were of single individuals and were likely Dusky Grouse (Dendragapus obscurus). Field investigations in the Beartooth Plateau, Bighorn Mountains, and Wind River Range outside of the Snowy Range revealed no ptarmigan or their sign. However, all unoccupied areas examined could potentially support White-tailed Ptarmigan populations, with the Wind River Range being most suitable, followed by the Bighorn Mountains and Beartooth Plateau. The lack of White-tailed Ptarmigan in alpine areas in Wyoming outside of the Snowy Range is most likely related to geologic events in the late Pleistocene period and not in the Holocene.
\end{abstract}

Resumen.-Encontramos trece ejemplares (11 pieles de museo, 2 esqueletos) del lagópodo coliblanco (Lagopus leucura), colectados en Wyoming durante el período de 1911-1967; doce pertenecientes al área de Snowy Range (Condado de Albany) y uno cerca de Encampment (Condado de Carbon). Las últimas observaciones comprobables del lagópodo coliblanco en Snowy Range datan de 1974, y provienen de dos informes separados, ambos de cuatro individuos del mismo lugar. El 15 de octubre del 2005 se constató, muy al norte del Snowy Range, un informe más reciente de dos aves. Ninguna de las observaciones constatadas ni las pruebas de colecta fueron de más de seis individuos. La mayoría de los registros de observación publicados de otras áreas distintas a Snowy Range son de un sólo individuo y corresponden, probablemente, a gallos de las rocosas (Dendragapus obscurus). Las investigaciones de campo llevadas a cabo en Beartooth Plateau, Bighorn Mountains y Wind River Range, en las afueras de Snowy Range, no revelaron la presencia o señales del lagópodo. Sin embargo, todas las áreas inhabitadas examinadas podrían respaldar la presencia de poblaciones de lagópodos coliblancos, siendo Wind River Range el más adecuado, seguido de Bighorn Mountains y Beartooth Plateau. La ausencia de lagópodos coliblancos en áreas alpinas de Wyoming, en las afueras de Snowy Range, está probablemente más relacionada a sucesos geológicos de la antigua era del Pleistoceno, no así de la era del Holoceno.

White-tailed Ptarmigan (Lagopus leucura; hereafter ptarmigan) have a discontinuous distribution in western North America with large gaps that relate to the locations of alpine habitats (Aldrich and Duvall 1955, Braun et al. 1993). This scattered and discontinuous distribution, along with recent concerns about climate change, has led to a petition to list 2 subspecies as threatened or endangered under the Endangered Species Act (Center for Biological Diversity 2010). One of the subspecies, L. l. altipetens, occurs in the Rocky Mountains south of Montana, and the other subspecies, L. l. rainierensis, occurs in Washington State. The U.S. Fish and Wildlife Service returned a positive 90-day finding, indicating the petition for listing the 2 subspecies may be warranted (USDI 2012).
Wyoming has the smallest distribution of habitat occupied by ptarmigan within the range of the species (Braun et al. 1993). Knowledge of this species in Wyoming is limited (Hoffman 2006, Orabona et al. 2012). The earliest mention of ptarmigan in Wyoming was by Batty (1874), who collected several adults and one chick in the Sierra Madre Mountains. The next was by Bendire (1892:83), who reported that W.M. Wolfe of Kearney, Nebraska, "found ptarmigan in the Wind River Mountains, Wyoming." Knight (1902:55) reported that ptarmigan were "resident and quite common in alpine districts." He reported "the only Wyoming record is based on my own observation in the Medicine Bow Mountains" and indicated seeing "an old bird with a covey of ten or a dozen young that were less than half

\footnotetext{
${ }^{1}$ Grouse Inc., 5572 N. Ventana Vista Road, Tucson, AZ 85750. E-mail: sgwtp66@gmail.com

${ }^{2}$ Natural Resource Ecology Laboratory, Department of Ecosystem Science and Sustainability, Colorado State University, Fort Collins, CO 80523.
} 
grown” in July 1890. Cary (1917:51) reported ptarmigan only from the Medicine Bow Range (hereafter Snowy Range unless specified as the Medicine Bow Mountains in the original citation) and did not record this species in the Teton, Wind River, or Absaroka ranges. McCreary (1939:28) indicated ptarmigan were frequently seen in the Snowy Range and also included a report on Cloud Peak in the Bighorn Mountains (sight record attributed to A.G. Burkert). Gates (1940:20) reported that "ptarmigans" were among the birds less commonly observed at the Science Summer Camp above Centennial in the Snowy Range. More recently, Harju (1977) reported that in about 1972 he spent 3 days in the Snowy Range looking for ptarmigan and saw one. He also reported that ptarmigan were recently observed from the west side of the Tetons and Yellowstone National Park and may occur in the Absaroka and Wind River ranges. However, no documentation was provided for these areas. Madsen (1996:8) also mentioned that ptarmigan occur in the Snowy Range. Orabona et al. (2012) considered ptarmigan to be rare in Wyoming and identified only the Snowy Range as an area where breeding was likely to occur.

The scant literature and journal reports of ptarmigan in Wyoming often lacked details necessary to properly ascertain whether the observed birds were the species in question. Moreover, details were commonly insufficient to rule out Dusky Grouse (Dendragapus obscurus), which frequently are found in subalpine and alpine areas during the spring and summer (Hoffmann 1960, Pattie and Verbeek 1966, McEneaney 1995; C.E. Braun observations). Assessing the credibility of ptarmigan sight records is difficult in the absence of photographic or specimen documentation. Thus, specimen records were of primary interest to assess the occurrence of ptarmigan in Wyoming. Our objectives were to (1) compile and report all known specimen records of White-tailed Ptarmigan in Wyoming and (2) report and evaluate past records of this species based on the recorded descriptions. In addition, we surveyed alpine areas over a period of years for the presence of ptarmigan and the apparent suitability of these areas in Wyoming for the species. We discuss the historic extent of occupied areas in Wyoming and the uncertainty regarding the current status of ptarmigan in the state.

\section{Methods}

We solicited museums via the Ornithological Newsletter (1968-1969) for specimen records of White-tailed Ptarmigan collected in Wyoming. Museums with specimen records were visited at that time by C.E. Braun to record morphological characteristics of the specimens and collect sex and age information. We used contemporary search methods to locate additional specimens using online sources (GBIF, iDigBio, VertNet) and the search terms ptarmigan, Wyoming, Lagopus leucura, and Lagopus leucurus (searches performed in 2016). We also reviewed the literature (Google Scholar and Thomson Reuters Web of Science) and data from the citizen sciencebased project eBird (Sullivan et al. 2009) using the same search criteria and evaluated reported observations of ptarmigan in Wyoming and immediately adjacent areas in Montana.

Field surveys of Wyoming mountain ranges were taken at various times in the late 1960s through the 1980s by C.E. Braun, and in more recent years by both C.E. Braun and G.T. Wann (Snowy Range only). Surveys consisted of walking through apparently suitable ptarmigan habitat (Braun 1971) while searching for birds or their sign (feathers, tracks, droppings). We periodically played recordings of male territorial calls and/or chick distress calls during walking surveys (Braun et al. 1973). These methods have been used in Colorado since the late 1960s and have been highly successful in locating birds in breeding and summer habitats (Braun and Rogers 1971, Martin et al. 2000, Wann et al. 2014).

We visited the Snowy Range on 23 July and 11 August 1968, 12-14 August 1973, and more recently on 14 August 2015, 11 June 2016, and 22 August 2016. We searched all apparently suitable habitats within the vicinity of Medicine Bow Peak and Browns Peak. Alpine habitats in the Bighorn Mountains were searched from 21 August to 26 August 1977 (Braun 1977). Areas investigated included Dome Lake-Elk Peak, Powder River Pass-Baby Wagon Creek-Crazy Woman Creek, North Fork of Clear Creek-Soldier Park in the Cloud Peak Primitive Area, and the Lilly Lake-Bomber Mountain area, as well as the 
Table 1. Museum specimens of White-tailed Ptarmigan (Lagopus leucura) collected in Wyoming, USA. The table includes the museum where the specimen is stored (Museum ID: UWYMV = University of Wyoming Museum of Vertebrates; USNM = United States National Museum; AMNH = American Museum of Natural History; KUMNH = Kansas University Natural History Museum \& Biodiversity Institute; MVZ = Museum of Vertebrate Zoology at Berkeley). Age (juvenile $=$ bird hatched the same year as collected; adult $=$ bird 2 years of age or older; subadult $=$ bird less than one year of age; unknown = age could not be determined), sex, collection date, location (general location recorded for museum entry), and county (all specimens were collected in Wyoming) are provided for each specimen.

\begin{tabular}{|c|c|c|c|c|c|c|}
\hline $\begin{array}{l}\text { Museum } \\
\text { ID }\end{array}$ & $\begin{array}{l}\text { Specimen } \\
\text { ID }\end{array}$ & Age & Sex & $\begin{array}{l}\text { Collection } \\
\text { date }\end{array}$ & Location & County \\
\hline UWYMV & Bird 1620 & Juvenile & Unknown & $24 \mathrm{Jul} 1911$ & Snowy Range & Albany County \\
\hline UWYMV & Bird 170 & Adult & Female & $24 \mathrm{Jul} 1911$ & Snowy Range & Albany County \\
\hline USNM & 230369 & Adult & Female & 5 Jul 1911 & Medicine Bow Peak & Albany County \\
\hline USNM & 230370 & Unknown & Male & 5 Jul 1911 & Medicine Bow Peak & Albany County \\
\hline USNM & 230372 & Unknown & Female & 5 Jul 1911 & Medicine Bow Peak & Albany County \\
\hline AMNH & 129280 & Subadult & Unknown & 17 Feb 1916 & Near Encampment & Carbon County \\
\hline KUMNH & 24559 & Adult & Male & 29 Aug 1946 & Browns Peak & Albany County \\
\hline KUMNH & 24560 & Adult & Male & 29 Aug 1946 & Browns Peak & Albany County \\
\hline KUMNH & 24561 & Adult & Male & 29 Aug 1946 & Browns Peak & Albany County \\
\hline KUMNH & 24562 & Adult & Male & 29 Aug 1946 & Browns Peak & Albany County \\
\hline KUMNH & 47691 & Adult & Male & 29 Aug 1946 & Browns Peak & Albany County \\
\hline KUMNH & 47692 & Adult & Male & 29 Aug 1946 & Browns Peak & Albany County \\
\hline MVZ & 158990 & Adult & Male & 16 Sep 1967 & Medicine Bow Peak & Albany County \\
\hline
\end{tabular}

Burgess Junction-Woodchuck Pass and Granite Pass-Upper Goose Creek areas. During 8-14 August 1987, field surveys were conducted in the Wind River Range from Half Moon Lake over Washakie Pass and along the Bears Ears trail from about Valentine Lake to Sand Creek and Adams Pass at elevations from $3048 \mathrm{~m}$ to $3871 \mathrm{~m}$, a distance of about $60 \mathrm{~km}$ (Braun 1987, 1988). Portions of the Beartooth Plateau were searched during the summers of 1960-1965 (Pattie and Verbeek 1966) and in early summer 1968 by C.E. Braun and D.L. Pattie (Braun and Pattie 1969).

\section{RESUlTS}

\section{Museum Specimens}

We found 3 specimens of ptarmigan that had been collected in Wyoming on 5 July 1911 on Medicine Bow Peak in the Snowy Range, 2 specimens collected in the Snowy Range on 24 July 1911, one specimen collected on 17 February 1916 near Encampment (elevation $2402 \mathrm{~m}$, about $16 \mathrm{~km}$ from alpine areas in the Sierra Madre Mountains), and 6 specimens collected on 29 August 1946 on Browns Peak in the Snowy Range (Table 1). The most recent specimen record was taken on 16 September 1967 on Medicine Bow Peak (Table 1). All of these specimens were examined by C.E. Braun. The sex of one juvenile and one subadult (a bird $<1$ year of age) could not be determined, and the age class of one male and one female (skeletons) could not be determined (Table 1).

\section{Observational Records}

Evaluations of the few observational records dating to the 1920s in northern Wyoming supported evaluations by others (McEneaney 1995, Wright 1996), who indicated the records were suggestive of Dusky Grouse and not ptarmigan. These records lacked sufficient details to suggest they were ptarmigan, including the physical description of the birds and habitat characteristics of where they were observed. Moreover, the documented specimens of ptarmigan in the Snowy Range indicated that museums were actively collecting in Wyoming during the same time period, yet no specimens are known from the northern part of the state. This suggests ptarmigan were either absent or occurred only in low numbers. Two observational records of 4 ptarmigan each were recorded from Medicine Bow Peak on 15 August 1974 (eBird database) and 25 August 1974 (Paul Hendricks, personal communication). The observers were contacted and the reports were determined to be valid based on physical descriptions of the birds' appearance (i.e., "grouse-like birds" with "gray-brown feathers", which ruled out Dusky Grouse), behavior (in small flocks and "unwary" of observers), plumage coloration (in mid to late August appeared to be "gray-brown") and habitat ("near snowfield and boulders along ridgeline”), all of 
which are consistent with ptarmigan. It is likely these 2 observations were of the same birds. More recently, Faulkner (2010:59) reported that on 15 October 2005, S.W. Horn observed 2 ptarmigan below Rock Mountain about $3.2 \mathrm{~km}$ south of Arlington, Wyoming (Carbon County), at about 2728 m elevation in a mountain meadow type (Wyoming Bird Records Committee, and S.W. Horn personal communication to C.E. Braun). This is well north (about $24 \mathrm{~km}$ ) of the Snowy Range.

\section{Field Surveys}

Field investigations in the area of Medicine Bow Peak by C.E. Braun on 23 July and 11 August 1968 revealed recent winter sign (piles of winter droppings). G.T. Wann (with R.W. Hoffman) searched Medicine Bow Peak and adjacent areas on 14 August 2015 and Browns Peak and adjacent areas on 11 June 2016, and found no ptarmigan or sign. Likewise, C.E. Braun surveyed areas on Brooklyn Ridge in the Snowy Range on 22 August 2016 and found no ptarmigan or their sign.

No ptarmigan or sign (i.e., droppings, feathers) were observed by C.E. Braun during 6 days of searching in the Bighorn Mountains. The alpine plant composition in the area was mostly similar to that in Colorado, although the area was drier. Rock was abundant at higher elevations. Dryas octopetala and Salix (both prostrate dwarf forms and taller) were common and appeared to be sufficiently abundant to sustain ptarmigan in fall and winter (Braun 1977). Habitats in spring, similar to but drier than those in the Beartooth Plateau, may limit ptarmigan from breeding in the Bighorn Mountains.

C.E. Braun failed to locate any ptarmigan or sign during 7 days of searching in the Wind River Range. The alpine areas appeared to be excellent for ptarmigan, especially from Valentine Lake to past Sand Creek. Two species of mat Salix were observed, as well as taller forms of Salix. Snow fields were still present along sheltered ridgelines, and wet sites suitable for brood use were present. There appeared to be no shortage of potential breeding areas, summering areas, or wintering areas (Braun 1987, 1988).

\section{DisCUSSION}

All credible observational and specimen records of ptarmigan exist only from the
Snowy Range area of southern Wyoming. The available data from Wyoming indicate ptarmigan may occur as a breeding population only in the Snowy Range in Albany County. This is about $50-80 \mathrm{~km}$ north of populations on Clark Peak in northern Jackson County, Mt. Zirkel in western Jackson County, and Crown Point-Crown Mountain in Larimer County, Colorado (Fig. 1; Braun and Rogers 1971). The Snowy Range is visible from all of these areas; thus, dispersal of individuals from Colorado to Wyoming, though probably rare and sporadic, is possible given known dispersal distances for the species (Hoffman and Braun 1975, Giesen and Braun 1993). The report of S.W. Horn on 15 October 2005 of 2 ptarmigan well north of the Snowy Range near Arlington, Wyoming, is suggestive of movement in Wyoming and possibly movement between Colorado and Wyoming. Long movements of ptarmigan have been documented in Colorado as R.J. Niedrach reported 2 ptarmigan in Denver, well east of alpine areas, on 20 October 1941 following a fall storm in the mountains (Bailey and Niedrach 1965:255). C.E. Braun has also recorded ptarmigan from outside of alpine locations during October and December in northern Colorado (see also Hoffman and Braun 1975, Giesen and Braun 1993).

We found reports of collections but no specimens from the Sierra Madre Mountains (e.g., Batty 1874). These reports seem credible based on a subsequent collection (near Encampment in 1916), even though the elevation of the alpine area (Bridger Peak $=3354$ $\mathrm{m}$ ) in the Sierra Madre Mountains is lower than most occupied breeding habitats in Colorado and collection locations in the Snowy Range. However, there is linkage with the Mt. Zirkel Wilderness in the Park Range in adjacent Colorado where ptarmigan are known to occur (Braun and Rogers 1971). H.E. Anthony (per his collecting records), who collected 3 specimens on 5 July 1911 in the Snowy Range, also worked in the Sierra Madre Mountains during 16-21 June 1911, but did not collect any ptarmigan specimens. He also collected on Fremont Peak (the second highest mountain in Wyoming) near Pinedale during 17-25 July 1911 up to $3170 \mathrm{~m}$ and did not report ptarmigan.

We consider all observational records in the Medicine Bow Mountains/Snowy Range (Knight 1902, Cary 1917, McCreary 1939, 

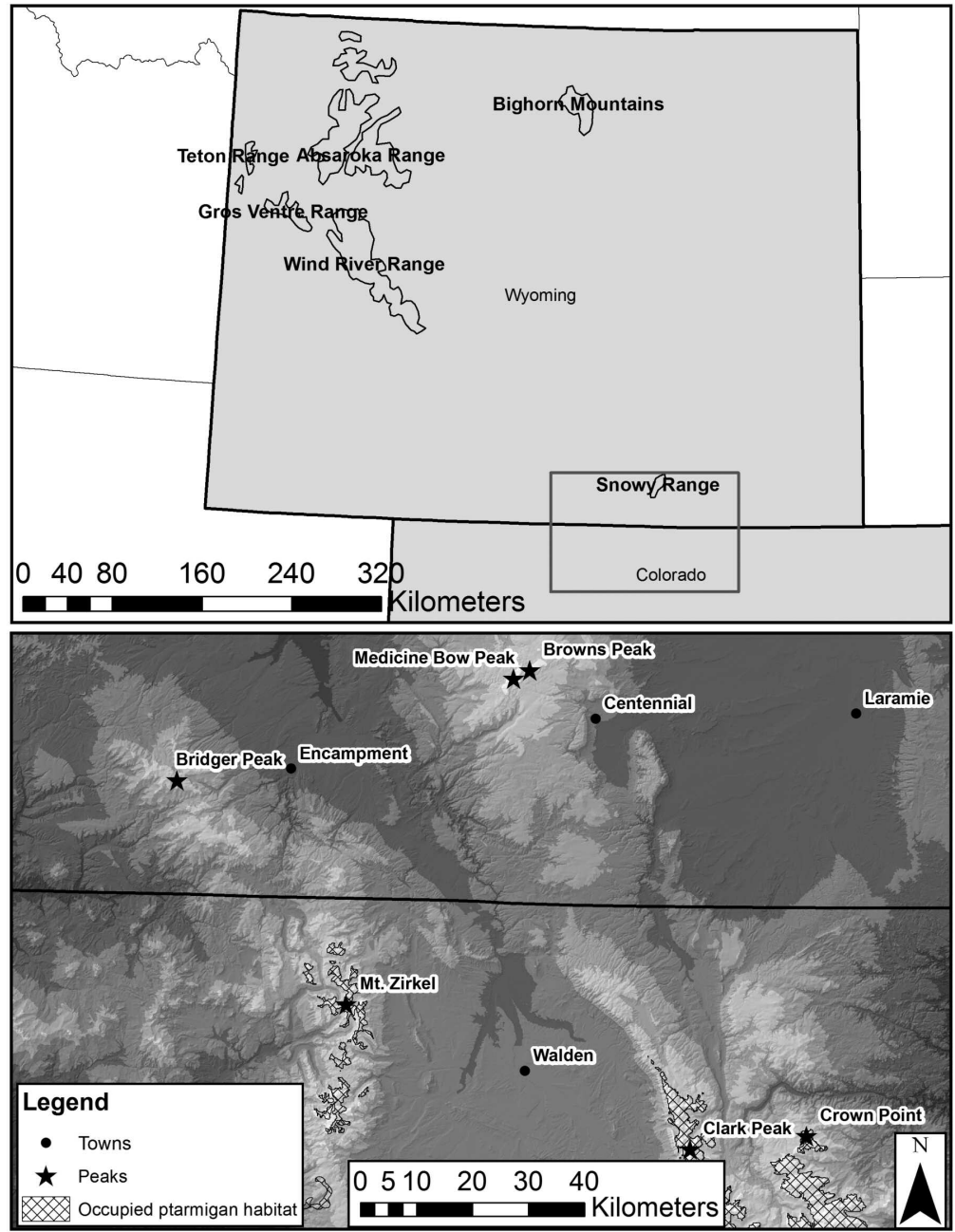

Fig. 1. Top panel: Extent of alpine habitat in Wyoming. Bottom panel: Areas of suitable habitat occupied by Whitetailed Ptarmigan (Lagopus leucura) in northern Colorado (polygons with hatch marks) and areas of historic occurrence in Wyoming (black stars, based on specimen records and observations).

Gates 1940, Harju 1977, Madsen 1996) to be valid. No data were found to support general statements that ptarmigan occurred in all alpine districts of Wyoming (Knight 1902:55, "Resident and quite common in all alpine districts"; also Grave and Walker 1913). We also could not find documentation for ptarmigan in the Wind River Range (Bendire 1892:83), or in the Bighorn Mountains, where McCreary (1939:28) included an observation on Cloud Peak. Canterbury et al. (2013:231) listed ptarmigan in the Bighorn Mountains as hypothetical.

Ptarmigan also have been reported in the northern area of Yellowstone National Park on Quadrant Mountain in the Gallatin Range
(Skinner 1927 [no date provided, Park County, MT], Rosche 1954 [20 July 1952, Mount Washburn, Park County, WY]). Both observations were above tree line, and both were of a single bird. There was an observation of 3 birds in October 1941 in conifers on Electric Peak, the highest mountain in the Gallatin Range (Park County, Montana) (McEneaney 1995). These observations have been disputed as unreliable (McEneaney 1995, Wright 1996) and have been ascribed to Dusky Grouse, an assessment with which we concur. Braun and Pattie (1969) worked on the Beartooth Plateau in this area in late spring 1968 and found no sign of ptarmigan. We conclude that this 
cluster of observations over the period from 1926 to 1954 does not represent a small population of ptarmigan.

There are reports of fossil specimens of Lagopus leucura from Little Box Elder Cave in Converse County and Little Canyon Creek Cave in Washakie County, Wyoming, during the late Pleistocene (Emslie 1985). These fossil records and the work of Mears (1981) suggest that steppe-tundra occurred during the late Pleistocene in the basins of southeastern Wyoming. Thus, it is likely that suitable habitats supported ptarmigan prior to the Holocene.

Why are there no ptarmigan in apparently suitable alpine areas in Wyoming when other components associated with ptarmigan habitat, such as avifauna and alpine flora, presence of snow fields and lush alpine meadows, and rock cover are present at and above tree line? Each alpine area is presently different in some respect such as being drier in the Bighorn Mountains, lacking snow-free areas near taller willows during the breeding period in the Beartooth Plateau, and having no apparent limitations in the Wind River Range (Braun 1988). We hypothesize that White-tailed Ptarmigan originated when ancestral ptarmigan were isolated during the Pleistocene in Colorado and New Mexico. Much of Wyoming was covered by ice sheets at that time with all but the highest peaks being covered by ice (Roberts 1970, Mears 1981). This was apparently not the case to the south in Colorado even though valley glaciers were common. The highest mountain tops in Wyoming were apparently not covered with ice but were exposed rock with little vegetation. Thus, they were unsuitable for colonization by ptarmigan as the birds moved north from southern refugia with melting of the ice sheets. Much of eastern and central Wyoming was steppetundra (Mears 1981, Emslie 1985) in the late Pleistocene, which may have allowed ptarmigan to colonize to the north. All apparent indications are that glaciers were common in the Wind River Range until "recently" in geologic time (Roberts 1970). Thus, alpine habitats in Wyoming are also likely recent in origin, and habitats now apparently suitable were not available during the late Pleistocene (Hoffmann and Taber 1967). The Snowy Range could have been occupied by ptarmigan moving north from the Mummy Range in Colorado or from Mt. Zirkel in the west across the Sierra Madre Mountains as birds pioneered north from the Park Range in Colorado. They may not have been able to move further north in Wyoming during the Holocene because of unsuitable habitats and distances involved. However, we believe it is likely that ptarmigan could now successfully occupy alpine habitats in Wyoming such as the Wind River Range, the Bighorn Mountains, and possibly even the Absaroka Range, just as transplants to Pike's Peak in Colorado (Hoffman and Giesen 1983) and to other previously unoccupied areas in California, Utah, and a portion of New Mexico have been successful (Braun et al. 2011).

We are not confident that ptarmigan persist in the Snowy Range since the most recent specimen record was in 1967 and the most recent verifiable observations were in 1974 . Habitat that appears suitable for ptarmigan in the Snowy Range encompasses $<10 \mathrm{~km}^{2}$ with poor connectivity (approximately $50-80 \mathrm{~km}$ ) to occupied habitats in Colorado. This area is smaller than the area occupied by ptarmigan on Pike's Peak (Hoffman and Giesen 1983) and in New Mexico (Braun and Williams 2015). The Snowy Range is mostly derived from quartzite, and many alpine sites appear to have low productivity (but see Smith 1969). Livestock grazing was once common in the Snowy Range (Johnson 1962), as well as herbicide treatments to alter alpine vegetative communities to benefit livestock (Smith and Alley 1966). To our knowledge these practices no longer occur in the alpine and subalpine areas of the Snowy Range. We also are aware that snowmobiling and other winter recreation occurs in the Snowy Range, including areas that are very likely to be used by ptarmigan as winter habitat (i.e., basins with willow along the eastern and southeastern faces of the Snowy Range). Currently there are no restrictions in place to keep snow machines out of these areas. The long-term effects of snow machines on wildlife and plant communities are poorly understood (Neumann and Merriam 1972, Lodico 1973) but these machines can have large detrimental impacts on alpine plant communities in the short term (Greller et al. 1974). We encourage the investigation of habitat and disturbance impacts of recreation in the Snowy Range given its status as the only area known to have recently supported ptarmigan in Wyoming. The U.S. Forest Service 
indicated that ptarmigan have been extirpated in the Medicine Bow Mountains in Wyoming (USDA 2003a, 2003b).

We could find no recent evidence of Whitetailed Ptarmigan persisting in the Snowy Range or anywhere in Wyoming. If ptarmigan occurred or still occur in mountain ranges in northern Wyoming, it seems reasonable there would be occasional movements outside of occupied habitats into areas where they would be encountered. Based on specimen records and verified observations, we conclude that White-tailed Ptarmigan only occurred in the Snowy Range in Wyoming and all other alpine areas did not support ptarmigan in recorded history, and do not at present, even though some of these areas may now be able to support viable populations of ptarmigan. Additional field investigations may yet reveal a small population somewhere in the Snowy Range.

\section{ACKNOWLEDGMENTS}

We thank C.H. Gibson of the U.S. Forest Service and R.W. Wilson of the Wyoming Game and Fish Department for encouraging C.E. Braun to explore alpine habitats in Wyoming, and E. Raper of the Wyoming Game and Fish Department for sharing fieldwork in the Bighorn Mountains. J.R. Grieb, Director of the Colorado Division of Wildlife, was supportive of loaning C.E. Braun to other agencies for specialized expertise. S.D. Emslie helped with literature searches and R.W. Hoffman helped with field searches in the Snowy Range. Their efforts are appreciated. We also thank curators of museum collections for their willingness to let us examine specimens in their care. Associate editor M. Morrison, reviewer R.W. Hoffman, and an unidentified reviewer provided helpful suggestions which improved the manuscript. We appreciate their help.

\section{Literature Cited}

Aldrich, J.W., AND A.J. Duvall. 1955. Distribution of American gallinaceous game birds. U.S. Fish and Wildlife Circular 34.

Bailey, A.M., and R.J. Niedrach. 1965. Birds of Colorado. Volume 1. Denver Museum of Natural History, Denver, CO.

BatTy, J.H. 1874. The White-tailed Ptarmigan.—Lagopus leucurus. Forest and Stream 1:390.

Bendire, C.E. 1892. Life histories of North American birds with special reference to their breeding habits and eggs. U.S. National Museum Special Bulletin No. 1, Smithsonian Institution.
Braun, C.E. 1971. Habitat requirements of Colorado White-tailed Ptarmigan. Proceedings of the Western States Game and Fish Commissioners 51:284-292.

Braun, C.E. 1977. Report to J.R. Grieb, Director, Colorado Division of Wildlife, Fort Collins, CO.

Braun, C.E. 1987. Report to the File. Colorado Division of Wildlife, Fort Collins, CO.

Braun, C.E. 1988. Occurrence and distribution of White-tailed Ptarmigan in Wyoming. Journal of the Colorado-Wyoming Academy of Science 20(1):10.

Braun, C.E., K. Martin, and L.A. Robb. 1993. Whitetailed Ptarmigan (Lagopus leucurus). The Birds of North America, Number 68.

Braun, C.E., and D.L. Pattie. 1969. A comparison of alpine habitats and White-tailed Ptarmigan occurrence in Colorado and northern Wyoming. Journal of the Colorado-Wyoming Academy of Science $7(2): 50$.

Braun, C.E., And G.E. Rogers. 1971. The White-tailed Ptarmigan in Colorado. Technical Publication 27, Colorado Division of Game, Fish and Parks, Denver, CO.

Braun, C.E., R.K. Schmidt Jr., and G.E. Rogers. 1973. Census of Colorado White-tailed Ptarmigan with tape-recorded calls. Journal of Wildlife Management 37:90-93.

Braun, C.E., W.P. Taylor, S.M. Ebbert, R.S.A. Kaler, and B.K. SANDERCOCK. 2011. Protocols for successful translocations of ptarmigan. Pages 339-348 in R.T. Watson, T.J. Cade, M. Fuller, G. Hunt, and E. Potopov, editors, Gyrfalcons and ptarmigan in a changing world. Volume 2. Peregrine Fund, Boise, ID.

Braun, C.E., and S.O. Williams III. 2015. History and status of the White-tailed Ptarmigan in New Mexico. Western Birds 46:233-243.

Canterbury, J.L., P.A. Johnsgard, and H.F. Downing. 2013. Birds and birding in Wyoming's Bighorn Mountains region. Zea Books, Lincoln, NE.

CARY, M. 1917. Life zone investigations in Wyoming. North American Fauna No. 42.

Center for Biological Diversity. 2010. Petition to list the White-tailed Ptarmigan, (Lagopus leucura) as a threatened species under the Endangered Species Act. Center for Biological Diversity, Portland, OR.

Emslie, S.D. 1985. The late Pleistocene (Rancholabrean) avifauna of Little Box Elder Cave, Wyoming. University of Wyoming Contributions to Geology 23: 63-82.

Faulkner, D.W. 2010. Birds of Wyoming. Roberts and Company, Greenwood Village, CO.

Gates, D. 1940. Notes on some summer birds of Carbon County, Southeastern Wyoming. Nebraska Bird Review 8:20-21.

Giesen, K.M., and C.E. Braun. 1993. Natal dispersal and recruitment of juvenile White-tailed Ptarmigan in Colorado. Journal of Wildlife Management 57:72-77.

Grave, B.H., AND E.P. Walker. 1913. The birds of Wyoming with an explanation of recent changes in their distribution. Economic aspects also considered. University of Wyoming, Laramie, WY.

Greller, A.M., M. Goldstein, and L. Marcus. 1974. Snowmobile impacts on three alpine plant communities. Environmental Conservation 1:101-110.

Harju, H. 1977. Avian adaptation to alpine tundra. Wyoming Wildlife 41(3):6-9.

Hoffman, R.W. 2006. White-tailed Ptarmigan (Lagopus leucura): a technical conservation assessment. USDA 
Forest Service, Rocky Mountain Region; [accessed 7 January 2017]. http://www.fs.fed.us/r2/projects/scp/ assessments/whitetailedptarmigan.pdf

Hoffman, R.W., and C.E. Braun. 1975. Migration of a wintering population of White-tailed Ptarmigan in Colorado. Journal of Wildlife Management 39: 485-490.

Hoffman, R.W., and K.M. Giesen. 1983. Demography of an introduced population of White-tailed Ptarmigan. Canadian Journal of Zoology 61:1758-1764.

Hoffmann, R.S. 1960. Summer birds of the Little Belt Mountains, Montana. Occasional Papers, Montana State University, Missoula 1:1-18.

Hoffmann, R.S., AND R.D. TABER. 1967. Origin and history of Holarctic tundra ecosystems, with special reference to their vertebrate faunas. Pages 143-170 in W.H. Osborn and H.E. Wright Jr., editors, Arctic and alpine environments. Indiana University Press, Bloomington, IN.

Johnson, W.M. 1962. Vegetation of high-altitude ranges in Wyoming as related to use by game and domestic sheep. University of Wyoming Agricultural Experiment Station Bulletin 387.

KNight, W.C. 1902. The birds of Wyoming. University of Wyoming Experiment Station Bulletin No. 5. University of Wyoming, Laramie, WY.

Lodico, N.J. 1973. Environmental effects of off-road vehicles. A review of the literature. U.S. Department of the Interior, Office of the Secretary, Research Services Branch, Office of Library Services, Bibliography Series No. 29.

Madsen, C. 1996. The ptarmigan in ptransition. Wyoming Wildlife 60(3):6-9.

Martin, K., P.B. Stacey, and C.E. Braun. 2000. Recruitment, dispersal, and demographic rescue in spatially-structured White-tailed Ptarmigan populations. Condor 102:503-516.

McCreary, O. 1939. Wyoming bird life. Revised edition. Burgess Publishing Co., Minneapolis, MN.

McEneaney, T. 1995. The White-tailed Ptarmigan in Yellowstone. Searching for a high country phantom. Yellowstone Science 3(2):6-7.

Mears, B., JR. 1981. Periglacial wedges and the late Pleistocene environment of Wyoming's intermontane basins. Quaternary Research 15:171-198.

Neumann, P.W., and H.G. Merriam. 1972. Ecological effects of snowmobiles. Canadian Field-Naturalist 86:207-212.

Orabona, A., C. Rudd, M. Grenier, Z. Walker, S. Patla, AND B. OAKLEAF. 2012. Atlas of birds, mammals, amphibians, and reptiles in Wyoming. Wyoming Game and Fish Department Nongame Program, Lander, WY.
Pattie, D.L., And N.A.M. Verbeek. 1966. Alpine birds of the Beartooth Mountains. Condor 68:167-176.

RoвerTs, M.F. 1970. Late glacial and postglacial environments in southeastern Wyoming. Palaeogeography, Palaeoclimatology, Palaeoecology 8(1):5-17.

Rosche, R.C. 1954. Notes on some summer birds of Yellowstone National Park. Wilson Bulletin 66:60.

Skinner, M.P. 1927. New additions to the Yellowstone Park list of birds. Condor 29:203-204.

Smith, D.R. 1969. Vegetation, soils and their relationships at timberline in the Medicine Bow Mountains, Wyoming. Science Monograph 17, University of Wyoming Agricultural Experiment Station. University of Wyoming, Laramie, WY.

Smith, D.R., AND H.P. Alley. 1966. Chemical control of alpine avens. Journal of Range Management 19: 376-378.

Sullivan, B.L., C.L. Wood, M.J. Iliff, R.E. Bonney, D. FinK, AND S. Kelling. 2009. eBird: a citizen-based bird observation network in the biological sciences. Biological Conservation 142:2282-2292.

[USDA] United States Department of Agriculture. 2003a. Medicine Bow National Forest revised land and resource management plan. U.S. Department of Agriculture, Forest Service, Rocky Mountain Region, Denver, CO.

[USDA] United States Department of Agriculture. 2003b. Threatened, endangered, and sensitive plants and animals. Chapter 2670 in FSM 2600-2003-1, Forest Service manual: wildlife, fish, and sensitive plant habitat management. U.S. Department of Agriculture, Forest Service, Rocky Mountain Region, Denver, CO.

[USDI] United States Department of the Interior. 2012. Endangered and Threatened Wildlife and Plants; 90-day finding on a petition to list the Southern White-tailed Ptarmigan and the Mt. Rainier White-tailed Ptarmigan as Threatened with Critical Habitat. U.S. Department of the Interior, Fish and Wildlife Service. Federal Register 77(108):33143-33155.

Wann, G.T., C.L. Aldridge, and C.E. Braun. 2014. Estimates of annual survival, growth, and recruitment of a White-tailed Ptarmigan population in Colorado over 43 years. Population Ecology 56: 555-567.

WRIGHT, P.L. 1996. Status of rare birds in Montana, with comments on known hybrids. Northwestern Naturalist 77:57-85.

Received 12 December 2016

Accepted 29 March 2017

Published online 11 July 2017 